\title{
Conclusive approach for evaluating bed sediments of Lake Nasser using different indices
}

\section{Mohsen M. Yousry}

Water Research Center, Nile Research Institute, El-Qanater El-Khairiya, Egypt.

\section{ABSTRACT}

The present study focuses on metals distribution in Lake Nasser sediments and the major objectives of this study are to define the sources of these metals and to select the best indices to be applied for heavy metals assessment. Superficial sediment samples were collected from 10 sites along Lake Nasser (from Arkeen section to Kalabsha section). Samples were detected by inductively coupled plasma for Cd, As, $\mathrm{Cr}, \mathrm{Pb}, \mathrm{Cu}, \mathrm{Ni}$ and $\mathrm{Zn}$. The results showed that, $\mathrm{Cd}$ and $\mathrm{As}$ recorded values were under detection limits in all sites and the trend of metals according to average concentrations follow the sequence of $\mathrm{Cu}>\mathrm{Zn}>\mathrm{Cr}>\mathrm{Ni}>\mathrm{Pb}$. The average concentrations of these metals were $106.2,72.1,56.4,50.7$ and $18.2 \mathrm{mg} / \mathrm{kg}$ respectively. Environmental assessment of sediments pollution by heavy metals was carried out using different indices. Pollution indices are powerful tools for ecological geochemical assessment. The commonly used pollution indices by heavy metals in sediments were classified as two types; single index and integrated index. Four single indices of contamination factor (Cf), ecological risk factor (Er), sediment enrichment factor (SEF) and new index of geo-accumulation (NIgeo) were illustrated. Five integrated indices of pollution load index (PLI), degree of contamination (Cd), modified degree of contamination $(\mathrm{mCd})$, sediment pollution index (SPI) and potential ecological risk index (RI) were also calculated. Based on these indices for identifying the level of heavy metals of Lake Nasser sediments beside applying statistical analysis (cluster variables); the sediment enrichment factor, sediment pollution index and potential ecological risk index were chosen as the best over the other indices. The results also indicated that $\mathrm{Cu}, \mathrm{Zn}, \mathrm{Cr}, \mathrm{Ni}$ and $\mathrm{Pb}$ in the surface sediment were primarily derived from crustal origin and the natural processes, such as weathering and erosion of bedrock are the main supply sources of heavy metals in sediments along Lake Nasser.

Keywords: heavy metals, surficial sediments, pollution index, sediment enrichment factor, Geoaccumulationindex, ecological risk index, sediment pollution index, Lake Nasser

\section{INTRODUCTION}

Heavy metals are the most common environmental pollutants and their occurrence in waters and biota indicate the presence of natural or anthropogenic activities. The metals generated by anthropogenic activities cause more environmental pollution than naturally occurring metals. The existence of heavy metals in aquatic environments has led to serious impacts on plant and animal life (Sheikh et al., 2007). Heavy metals contamination in aquatic environment has drawn particular attentions due to their toxicity, persistence and biological accumulation (Varol, 2011; Jian et al., 2012). Heavy metals have low solubility and accumulated on bottom sediments. Bottom lake sediments are sensitive indicators for monitoring pollutants as they act as a sink and carrier for contaminations in aquatic environment (Caeiro et al., 2005; Bai et al., 2011, Suresh et al., 2012). The measurements of pollutants in water are not 
conclusive due to water discharge fluctuations and short resident time. The study of bottom lake sediments plays an important role for their longer residence time, and the role is called the record of history (Mackay, 2001). Environmental quality indices are a powerful tool for development, evaluation and converging raw environmental information to decision makers, managers or for the public. In recent decades, different assessment indices have been applied into estuarine environment (Spencer et al., 2002; Caeiro et al., 2005). In this paper, different sediment quality indices were applied either single or integrated. For instance, sediment enrichment factor (SEF), contamination factor (Cf), ecological risk factor (Er) and new index of geoaccumulation (NIgeo), were considered as single indices. However, potential ecological risk index (RI), sediment pollution index (SPI), contamination degree (Cd), pollution load index (PLI), and modified degree of contamination ( $\mathrm{mCd}$ ) were considered as integrated indices.

The objectives of this study are i) to define the sources of these metals (natural or anthropogenic) in Lake Nasser, ii) to study the potential ecological risk of heavy metals and iii) to select the best indices applying for heavy metals assessment.

\section{MATERIALS AND METHODS}

\section{Study area and Sampling}

The study area, in Lake Nasser (Figure 1 and Table 1), was selected between Arkeen at Km 333.3to Kalabsha at Km 41 upstream the dam during December 2012 to January 2013. This area was chosen to cover the Egyptian part of Lake Nasser which extends to about $350 \mathrm{Km}$. Superficial sediment samples were collected from 10 sampling monitored sites along Lake Nasser.The samples were transferred into labeled polyethylene bags and stored in the laboratory in a freezer until the time of analysis.

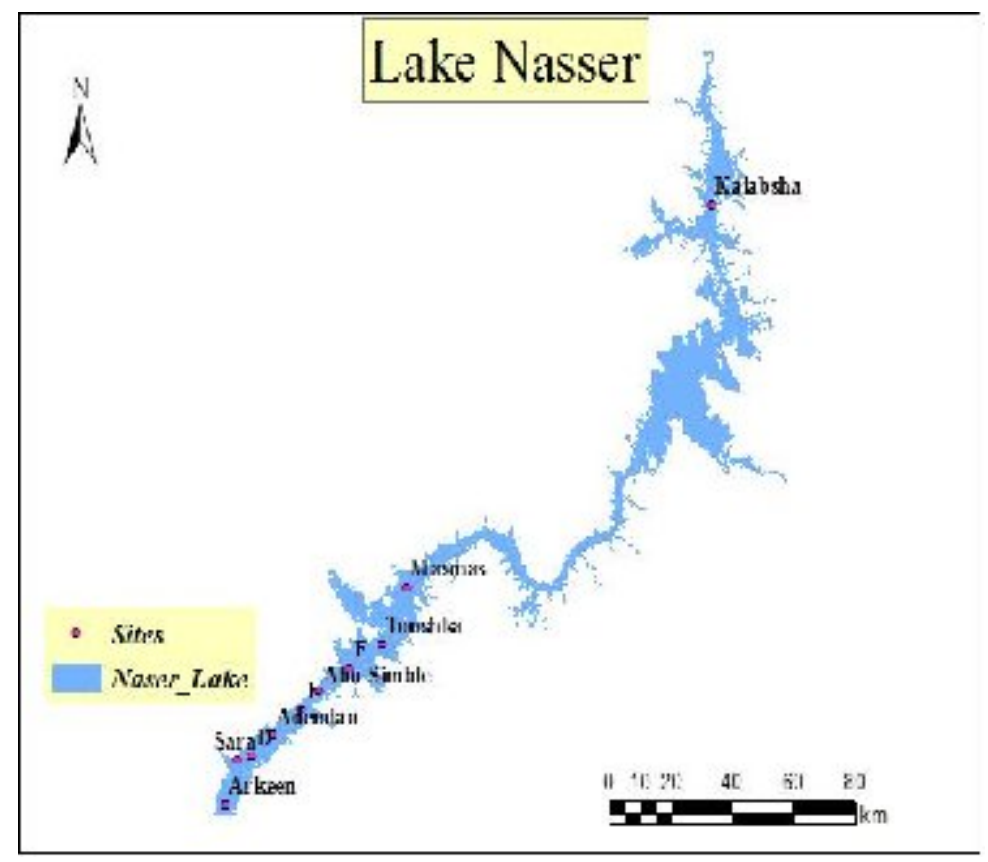

Fig. 1: Sites of sediment samples along Lake Nasser 
Table 1: Location of sediment samples

\begin{tabular}{|c|l|c|c|}
\hline Station No. & \multicolumn{1}{|c|}{ Site Name } & \multicolumn{2}{c|}{ Coordinates } \\
\hline & & $\mathrm{E}$ & $\mathrm{N}$ \\
\hline 1 & Arkeen & 328953.71 & 2436373.54 \\
\hline 2 & Sara & 33306.00 & 2449409.00 \\
\hline 3 & D (Between Sara and Adendane) & 337747.41 & 2450418.96 \\
\hline 4 & Adendan & 344024.03 & 2456878.76 \\
\hline 5 & E (Between Adendane and Abu-Simble) & 354114.00 & 2464288.00 \\
\hline 6 & Abu-Simble & 359611.00 & 2469915.00 \\
\hline 7 & F (Between Abu-Simble and Toushka) & 369691.00 & 2476277.00 \\
\hline 8 & Toushka & 380380.00 & 2483665.00 \\
\hline 9 & Masmas & 388206.00 & 2500164.00 \\
\hline 10 & Kalabsha & 488064.00 & 2613084.00 \\
\hline
\end{tabular}

\section{Heavy Metals Analysis}

Homogenized sediment samples were dried at $103^{\circ} \mathrm{C}$. The dried sediment samples were sieved from $63 \mu \mathrm{m}$ sieve size for metal analysis. Total heavy metals including $\mathrm{Cd}, \mathrm{As}, \mathrm{Pb}, \mathrm{Cr}, \mathrm{Ni}, \mathrm{Zn}$ and $\mathrm{Cu}$ were extracted by aqua-regia $\left(\mathrm{HCL}: \mathrm{HNO}_{3}=\right.$ 3: 1) using a hotplate maintaining a heating temperature of about $110^{\circ} \mathrm{C}$ (Binning and Baird, 2001). The extract solution was determined by ICP-MS.

\section{Statistical analysis}

Descriptive statistics and Cluster variables were applied using Minitab 16 Software.

\section{Environmental Assessment of Heavy Metals}

\section{Pollution Indices}

The pollution indices can be classified into two types i) Single indices, and ii) Integrated indices as illustrated in Table (2).

Table 2: Summarizes of the Different Sediment Quality Indices used in this Study.

\begin{tabular}{|c|c|c|}
\hline Sediment Quality Index & Parameters & Evaluation \\
\hline Contamination factor & $\mathrm{C}_{0-1}^{\mathrm{i}}$ : mean content of metal & $<1$ low contamination \\
\hline $\begin{array}{l}C_{f}^{i}=C_{0-1}^{i} / C_{n}^{i} \\
\text { (Hakanson 1980) }\end{array}$ & $\begin{array}{l}\mathrm{C}_{\mathrm{n}}{ }^{\mathrm{i}} \text { :pre-industrial concentration } \\
\text { of metal }\end{array}$ & $\begin{array}{l}1 \leq C_{f}^{i}<3 \text { moderate contamination } \\
3 \leq C_{f}^{i}<6 \text { considerable contamination } \\
6 \leq C_{f}^{i} \text { very high contamination }\end{array}$ \\
\hline $\begin{array}{l}\text { Sediment Enrichment factor } \\
\mathrm{SEF}=\mathrm{C}_{\mathrm{i}}-\mathrm{C}_{0} / \mathrm{C}_{0} \text { (Riba } \text { et al., 2002) }\end{array}$ & $\begin{array}{l}C_{i}: \text { total concentration of each metal } \\
C_{0} \text { : background level of metal }\end{array}$ & $\begin{array}{l}<1 \text { crustal origin } \\
>1 \text { anthropogenic origin }\end{array}$ \\
\hline $\begin{array}{l}\text { New Index of geoaccumulation } \\
\mathrm{NI}_{\text {geo }}=\operatorname{lnC}_{\mathrm{n}} / 1.5 \times \mathrm{B}_{\mathrm{n}} \\
(\mathrm{Ruiz}, 2001)\end{array}$ & $\begin{array}{l}C_{n} \text { : concentration of each meta } \\
B_{n} \text { : geochemical background of metal }\end{array}$ & $\begin{array}{l}\text { Unpolluted } \mathrm{NI}_{\mathrm{geo}}<1 \\
\text { value Very lightly polluted } 1<\mathrm{NI}_{\mathrm{geo}}<2 \\
\text { Lightly polluted } 2<\mathrm{NI}_{\mathrm{geo}_{0}}<3 \\
\text { Very highly polluted } \mathrm{NI}_{\mathrm{geo}}>5 \\
\text { Highly polluted } 4<\mathrm{NI}_{\mathrm{geo}}<5 \\
\text { Moderately polluted } 3<\mathrm{NI}_{\mathrm{geo}_{0}}<4\end{array}$ \\
\hline $\begin{array}{l}\text { Ecological risk factor } \\
\text { Er }^{i}=\operatorname{Tr}^{i} \cdot C_{f}^{i} \\
(\text { Hakanson 1980) } \\
\text { Toxic response factor } \\
(C u \text { and } P b=5, C r=3, Z n=1)\end{array}$ & $\begin{array}{l}T^{i} \text { : toxic response factor } \\
C_{f}^{i} \text { : contamination factor }\end{array}$ & $\begin{array}{l}\text { Low riskEr } r^{i}<40 \\
\text { Moderate risk } 40 \leq \mathrm{Er}^{i}<80 \\
\text { Very high risk } \mathrm{Er}^{i} \geq 320 \\
\text { High risk } 160 \leq \mathrm{Er}^{\mathrm{i}}<320 \\
\text { Considerable risk } 80 \leq \mathrm{Er}^{\mathrm{i}}<160 \\
\end{array}$ \\
\hline $\begin{array}{l}\text { Contamination degree } \\
\text { (Hakanson 1980) } \\
\mathbf{C}_{\mathbf{d}}=\sum \mathbf{C}_{\mathrm{f}}^{\mathbf{i}}\end{array}$ & $\mathrm{C}_{\mathrm{f}}^{\mathrm{i}}$ : contamination factor & $\begin{array}{l}C_{d}<8 \text { low degree of contamination } \\
8 \leq C_{d}<16 \text { moderate contamination } \\
16 \leq C_{d}<32 \text { considerable contamination } \\
\text { Very high degree of contamination } C_{d} \geq 32\end{array}$ \\
\hline $\begin{array}{l}\text { Modified degree of contamination } \\
\mathrm{mC}_{\mathrm{d}}=\sum \mathrm{C}_{\mathrm{f}}^{\mathrm{i}} / \mathbf{n} \\
(\text { Hakanson 1980) }\end{array}$ & $\begin{array}{l}\mathrm{C}_{\mathrm{f}}^{\mathrm{i}} \text { : contamination factor } \\
\mathrm{n} \text { : number of metals }\end{array}$ & $\begin{array}{l}\mathrm{mC}_{\mathrm{d}} \geq 32 \text { ultra-high degree of contamination } \\
1.5 \leq m C_{\mathrm{d}}<2 \text { low degree of contamination } \\
2 \leq \mathrm{mC}_{\mathrm{d}}<4 \text { moderate degree of contamination } \\
4 \leq \mathrm{mC}_{\mathrm{d}}<8 \text { high degree of contamination } \\
8 \leq \mathrm{mC}_{\mathrm{d}}<16 \text { very high degree of contamination } \\
16 \leq \mathrm{mC}_{\mathrm{d}}<32 \text { extremely high degree of contamination } \\
m C_{d}<1.5 \text { nil to very low degree of contamination }\end{array}$ \\
\hline $\begin{array}{l}\text { Potential ecological risk } \\
\text { Erí : Ecological risk factor } \\
\mathrm{RI}=\sum_{i=1}^{\mathrm{E}} \text { Eri (Hakanson 1980) }\end{array}$ & & $\begin{array}{l}\mathrm{RI}<150 \text { low risk } \\
150 \leq \mathrm{RI}<300 \text { moderate risk } \\
300 \leq \mathrm{RI}<600 \text { considerable risk } \\
\mathrm{RI} \geq 600 \text { very high risk }\end{array}$ \\
\hline 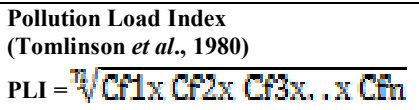 & $\mathrm{C}_{\mathrm{f}}^{\mathrm{i}}$ : contamination factor & $\begin{array}{l}\text { PLI }<1 \text { unpolluted sediment } \\
\text { PLI }>1 \text { polluted sediment }\end{array}$ \\
\hline $\begin{array}{l}\text { Sediment Pollution Index } \\
\mathrm{SPI}=\sum\left(\mathrm{EF}_{\mathrm{m}} * \mathbf{W}_{\mathrm{m}}\right) / \sum \mathbf{W}_{\mathrm{m}} \\
(\text { Singh } \text { et al., 2002) }\end{array}$ & $\begin{array}{l}\text { EF: enrichment factor } \\
W=\text { toxicity weight of metal } m\end{array}$ & $\begin{array}{l}\text { 0-2 natural sediment } \\
\text { 2-5 low polluted sediment } \\
5-10 \text { moderately polluted sediment } \\
\text { 10-20 highly polluted sediment } \\
\text { >20 dangerous sediment }\end{array}$ \\
\hline
\end{tabular}




\section{RESULTS AND DISCUSSION}

\section{Heavy metal concentrations}

The results of descriptive statistics of total metal concentrations at different sampling sites are shown in Table (3). It can be seen from the data that the concentrations $\left(\mathrm{mg} \mathrm{kg}^{-1}\right)$ of the five metals varied widely as follows: $\mathrm{Ni}, 34-86 \mathrm{mg}$ $\mathrm{kg}^{-1}$; Cr, 42-68 mg kg${ }^{-1}$; Cu, 73-124 mg kg ; Pb, 8-36 mg kg-1 and $\mathrm{Zn}, 53-93 \mathrm{mg} \mathrm{kg}^{-1}$. The mean metal concentrations in Lake Nasser decrease in the order $\mathrm{Cu}>$ $\mathrm{Zn}>\mathrm{Cr}>\mathrm{Ni}>\mathrm{Pb}$.

Table 3: Descriptive statistics of heavy metals measured in Lake Nasser

\begin{tabular}{|c|c|c|c|}
\hline Metals & \multicolumn{2}{|c|}{ Descriptive Statistics } & $\begin{array}{l}\text { Canadian Guidelines for } \\
\text { Agricultural Land use }\end{array}$ \\
\hline \multirow{6}{*}{$\mathrm{Ni}$} & Mean & 50.70 & 50 \\
\hline & Median & 45.00 & \\
\hline & Std. Deviation & 16.42 & \\
\hline & Minimum & 34.00 & \\
\hline & Maximum & 86.00 & \\
\hline & Range & 52.00 & \\
\hline \multirow{6}{*}{$\mathrm{Cr}$} & Mean & 56.40 & 64 \\
\hline & Median & 55.00 & \\
\hline & Std. Deviation & 7.68 & \\
\hline & Minimum & 42.00 & \\
\hline & Maximum & 68.00 & \\
\hline & Range & 26.00 & \\
\hline \multirow{6}{*}{$\mathrm{Cu}$} & Mean & 106.20 & 63 \\
\hline & Median & 116.50 & \\
\hline & Std. Deviation & 19.23 & \\
\hline & Minimum & 73.00 & \\
\hline & Maximum & 124.00 & \\
\hline & Range & 51.00 & \\
\hline \multirow{6}{*}{$\mathrm{Pb}$} & Mean & 18.20 & 70 \\
\hline & Median & 14.50 & \\
\hline & Std. Deviation & 10.65 & \\
\hline & Minimum & 8.00 & \\
\hline & Maximum & 36.00 & \\
\hline & Range & 28.00 & \\
\hline \multirow{6}{*}{$\mathrm{Zn}$} & Mean & 72.10 & 200 \\
\hline & Median & 69.50 & \\
\hline & Std. Deviation & 13.57 & \\
\hline & Minimum & 53.00 & \\
\hline & Maximum & 93.00 & \\
\hline & Range & 40.00 & \\
\hline
\end{tabular}

These mean concentrations of the heavy metals were found within the allowable limits of agricultural land use (Canadian Guidelines, 2007) except that of $\mathrm{Cu}$ which exceeds the values recommended by the standards. It is worth to mention that, 
Cadmium and Arsenic are not detected in all sites. Copper $(\mathrm{Cu})$ is an essential trace element that can betoxic to aquatic biota at high concentrations. Because the variety of organisms live in, or are in contact with bed sediments, sediments act as an important route of exposure to aquatic organisms.

Copper enters aquatic systems through aerial deposition or surface runoff. Because of its affinity forparticulate matter, mainly fractions of iron, manganeseoxides, and organic matter, $\mathrm{Cu}$ tends to accumulate insediments (Campbell and Tessier, 1996).

\section{Environmental Assessment}

Different sediment quality indices were applied including sediment enrichment factor (SEF), contamination factor (Cf), ecological risk factor (Er), New index of geoaccumulation (NIgeo) which consider as single indices and potential ecological risk index (RI), sediment pollution index (SPI), contamination degree (Cd), pollution load index (PLI), modified degree of contamination $(\mathrm{mCd})$ as integrated indices. The single contamination index only reflects the contamination of single heavy metals. However, in the natural environment, heavy metal contamination is always concomitant and combined. Therefore, the comprehensive contamination index provides the onlyconcrete evaluation of the overall pollution.

In this study, for the index calculation the pre-industrial reference level was chosen as the agricultural land use standards which close to the values recommended by Hakanson(1980).

Single Indices

Single indiceswere calculated for five heavy metals and the results are illustrated in Figures (2-5). The results of calculation of contamination factor (Cf) showed that, Lake Nasser sediment was low contaminated by $\mathrm{Pb}, \mathrm{Cr}$ and $\mathrm{Zn}$ $(\mathrm{Cf}<1)$, while it is moderately contaminated by $\mathrm{Cu}$ in all sites and $\mathrm{Ni}$ in four sites, where $\mathrm{Cf}>1$ (Figure 2).

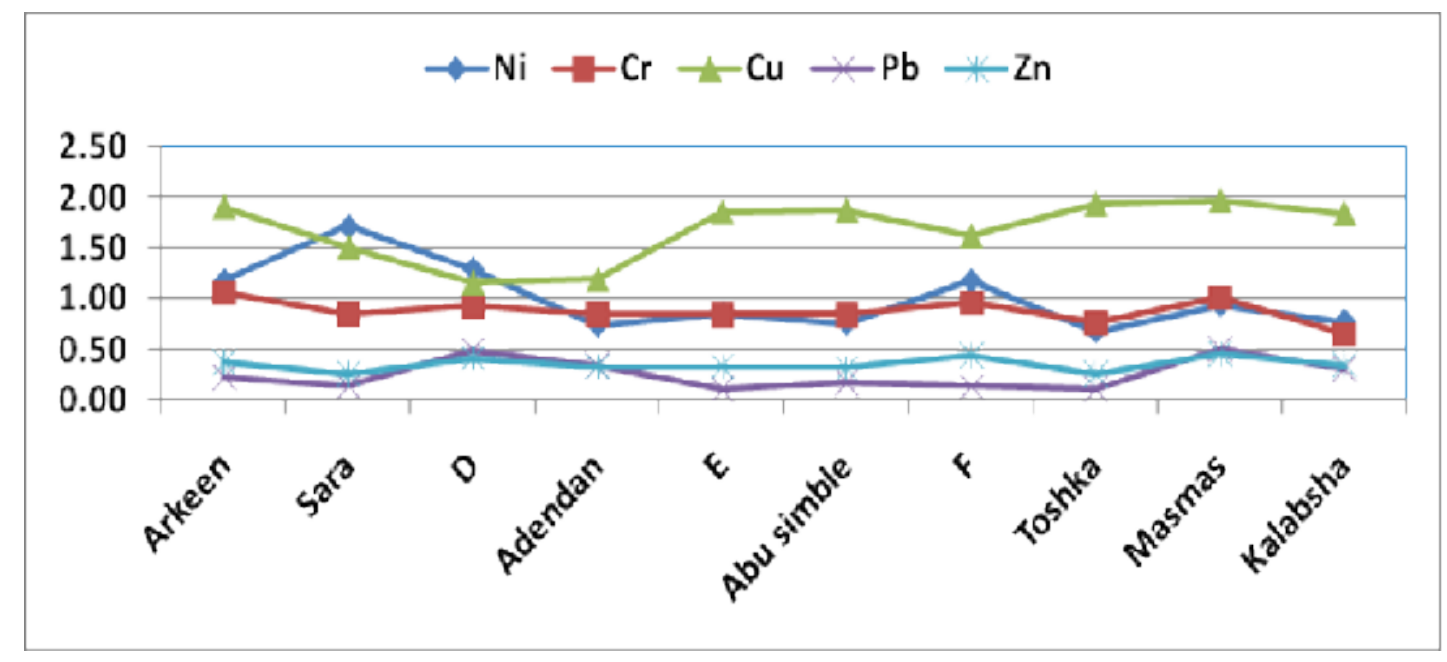

Fig. 2: Contamination factor in bed sediment along Lake Nasser

Sediment enrichment factor (SEF) calculation showed that, the heavy metals in bed sediment along Lake Nasser are crustal origin (natural) where SEF $<1$ in all sites for all heavy metals. The sediment enrichment factor has the advantage of being 
simple to compute and giving the source of heavy metals in bed sediment as revealed in Figure (3).

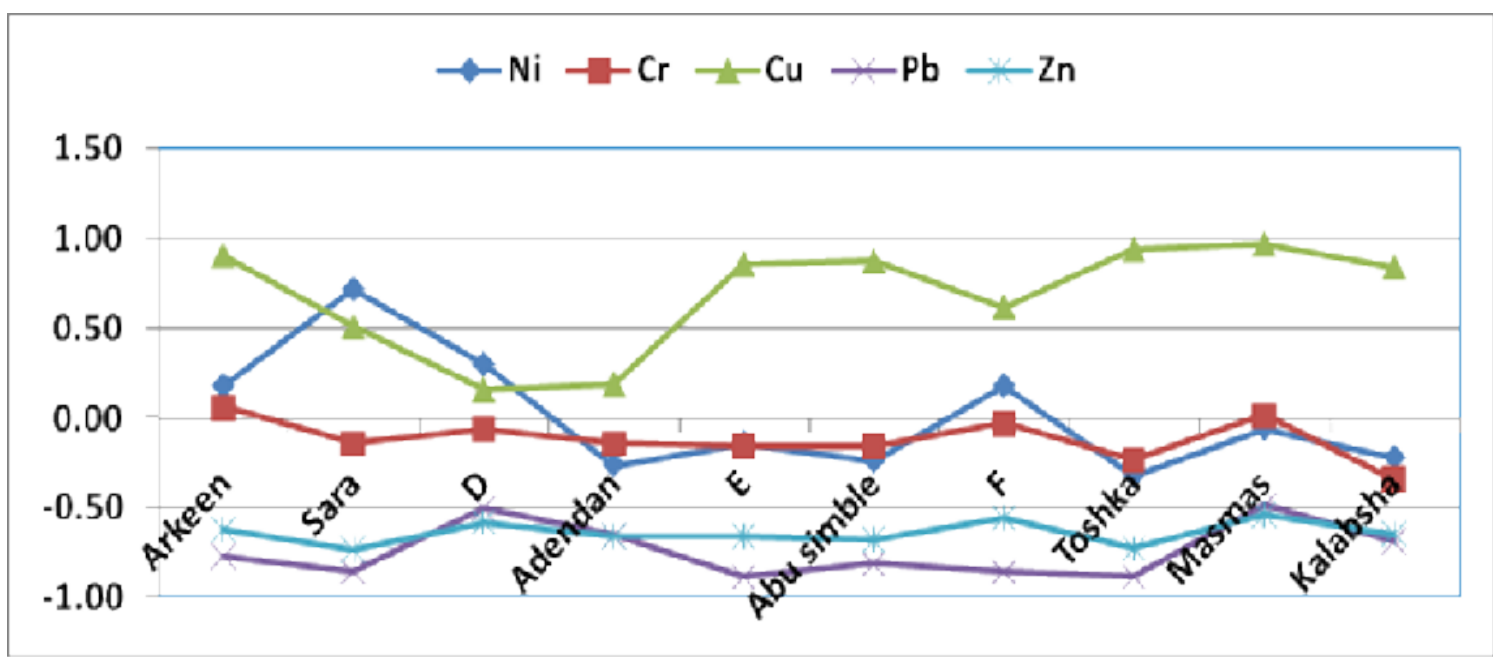

Fig. 3: Sediment enrichment factor in bed sediment along Lake Nasser

New Index of geoaccumulation ( $\mathbf{N I}_{\text {geo }}$ ) calculation indicated that, Lake Nasser sediments are unpolluted by heavy metals where $\mathrm{NI}_{\text {geo }}<1$ for all metals (Fig. 4).

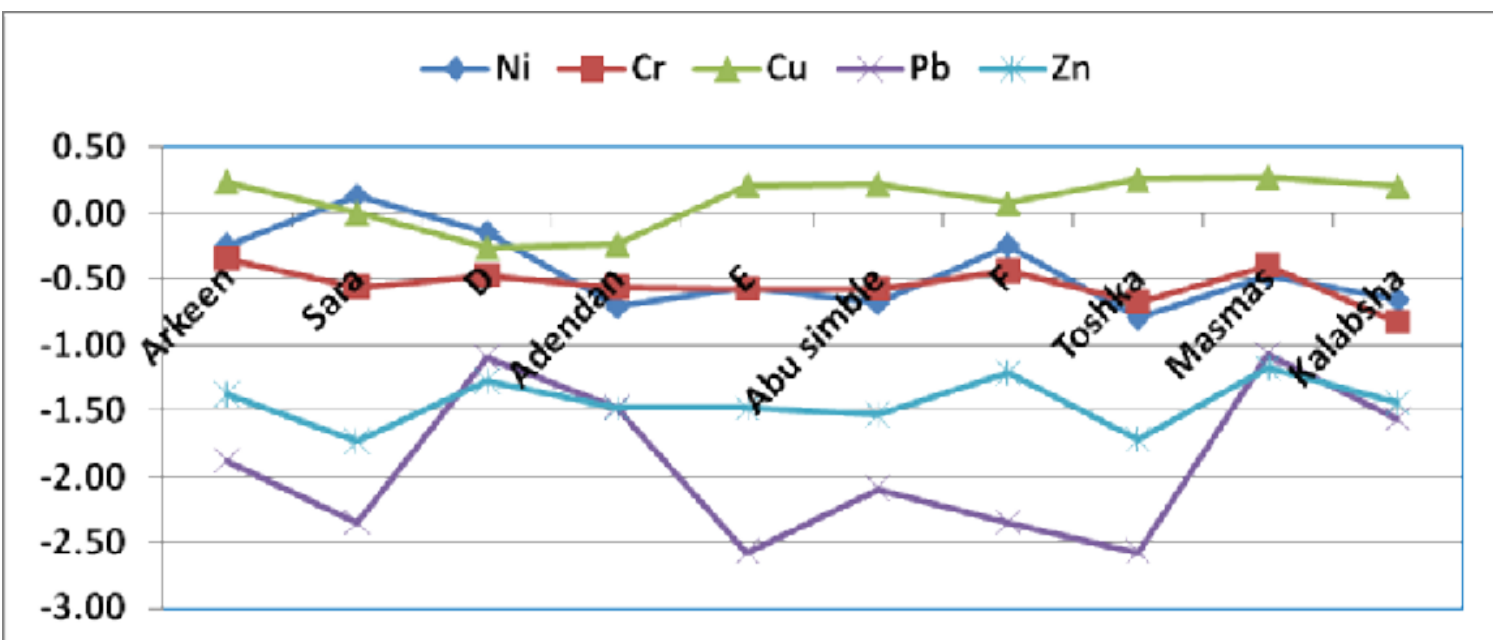

Fig. 4: Index of geoaccumulationin bed sediment along Lake Nasser

Ecological risk factor (Er) was applied to detect the potential ecological level of heavy metals in sediments from the Lake Nasser. The calculated ecological risk factor indicated that, the four heavy metals were at low risk, where $\mathrm{Er}<40$ (Fig. 5). Its worth mentioning that, Ni doesn't has toxic response factor. 


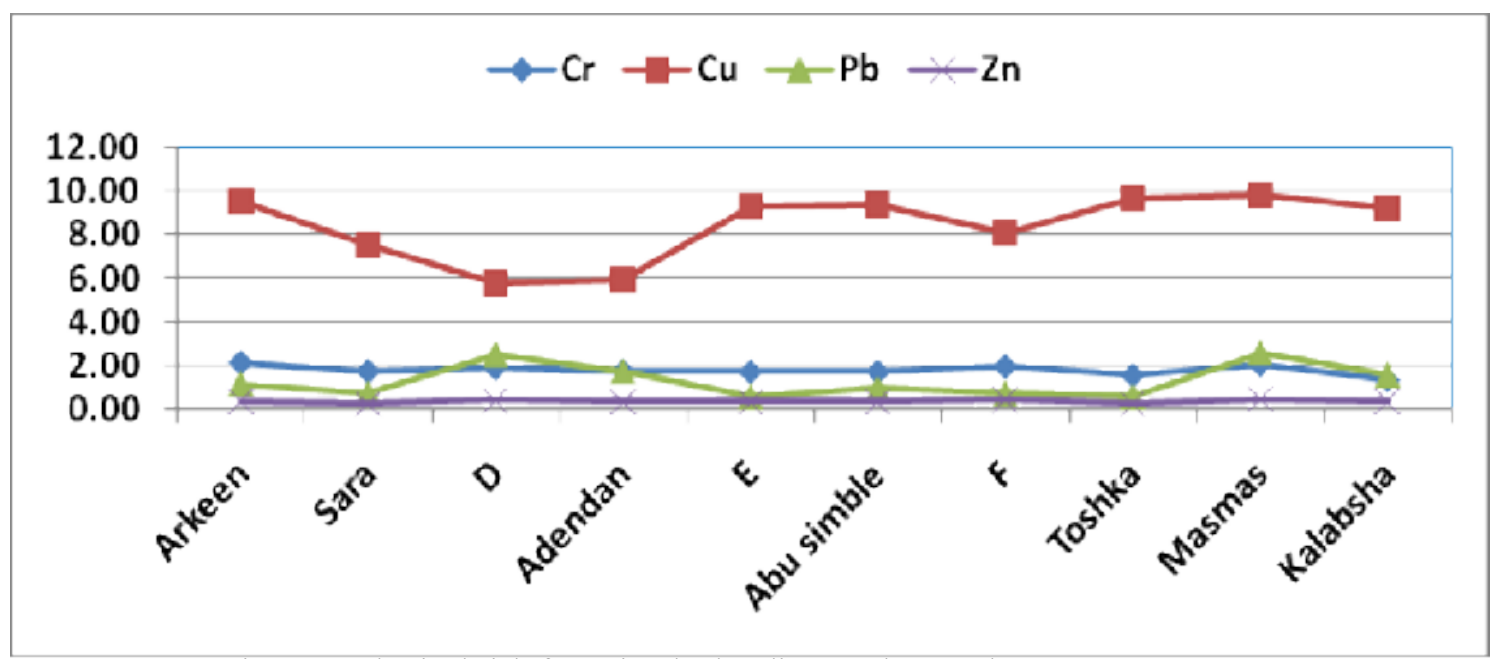

Fig. 5: Ecological risk factoring bed sediment along Lake Nasser

\section{Integrated Indices}

Five integrated indices of pollution load index, degree of contamination, modified degree of contamination, sediment pollution index and potential ecological risk index were also calculated (Fig. 6-7).

The contamination degree $\left(\boldsymbol{C}_{d}\right)$ was aimed at providing a measure of the degree of overall contamination in surface layer of bottom sediment along Lake Nasser. The results of $\mathrm{C}_{\mathrm{d}}$ calulation shwoed that, its values ranged between 3.47 to 4.9 and the sediment is classified as low degree of contamination by heavy metals $\left(\mathrm{C}_{\mathrm{d}}<8\right)$ as shown in Figure (6).

The potential ecological risk index (RI) was in the same manner as the degree of contamination defined as the sum of the risk factors. The potential ecological risk assessment was applied to detect the potential ecological risk level of heavy metals in sediments from the Lake Nasser. Calculated potential ecological risk index are presented in Figure 6 and their values ranged from 9.73 to 14.91 and the sediments were at low risk level by heavy metals.

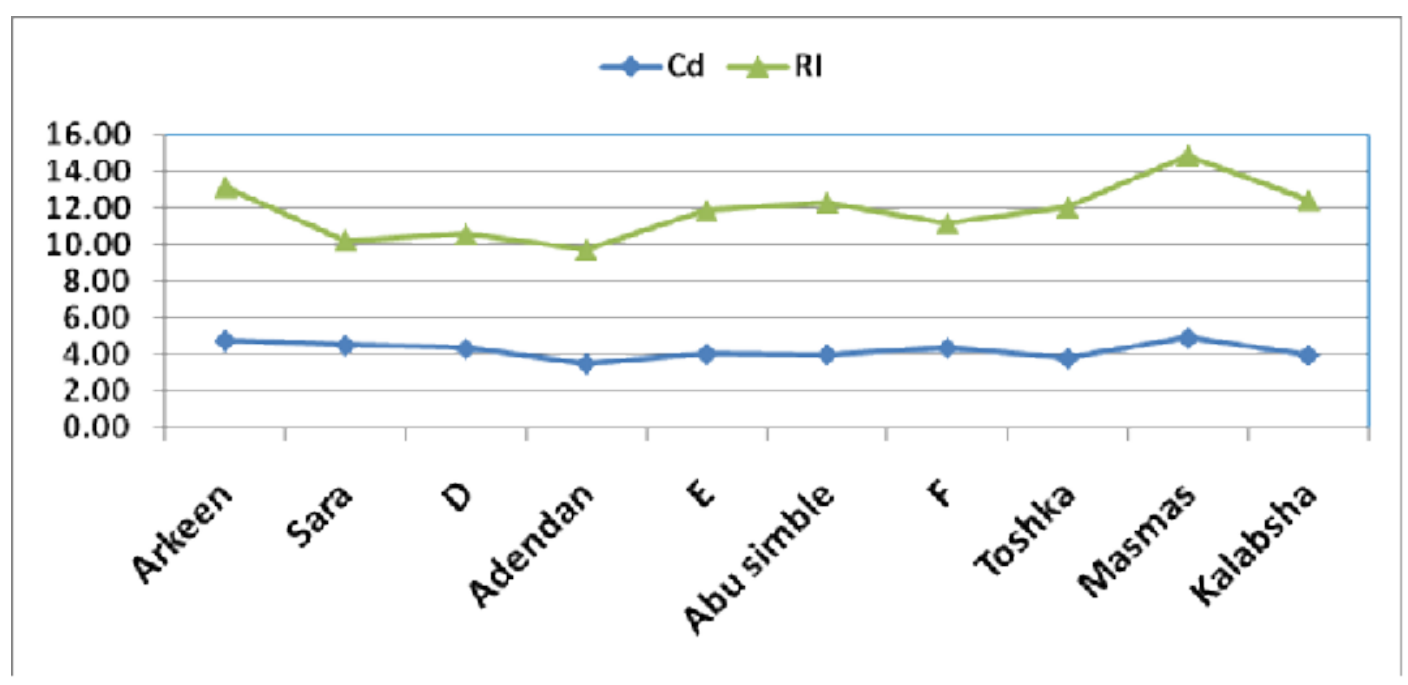

Fig. 6: $\mathrm{C}_{\mathrm{d}}$ and $\mathrm{RI}$ in bed sediment along Lake Nasser

The results of modified degree of contamination $\left(\boldsymbol{m} \boldsymbol{C}_{d}\right)$ calculation showed that, its values ranged between 0.69 and 0.98 and the sediments were classified as nil to very low degree of contamination as indicated in Figure (7). 
Sediment Pollution Index (SPI): A multi-metal approach has been introduced for an overall assessment of sediment quality with respect to heavy metals concentrations along with proper consideration to the relative metal toxicity. Figure (7) shows the variation in SPI classes of the Lake Nasser. Stream sediments from Lake Nasser are categorized into SPI0 natural sediments in all sites.

The pollution load index (PLI) was proposed by Tomlinson et al. (1980) for detecting pollution which permits a comparison of pollution levels between sites. The results of PLI calculation indicated that, the sediment along Lake Nasser are unpolluted by heavy metals where PLI ranged between 0.50 and $0.85(\mathrm{PLI}<1)$ as shown in Figure (7).

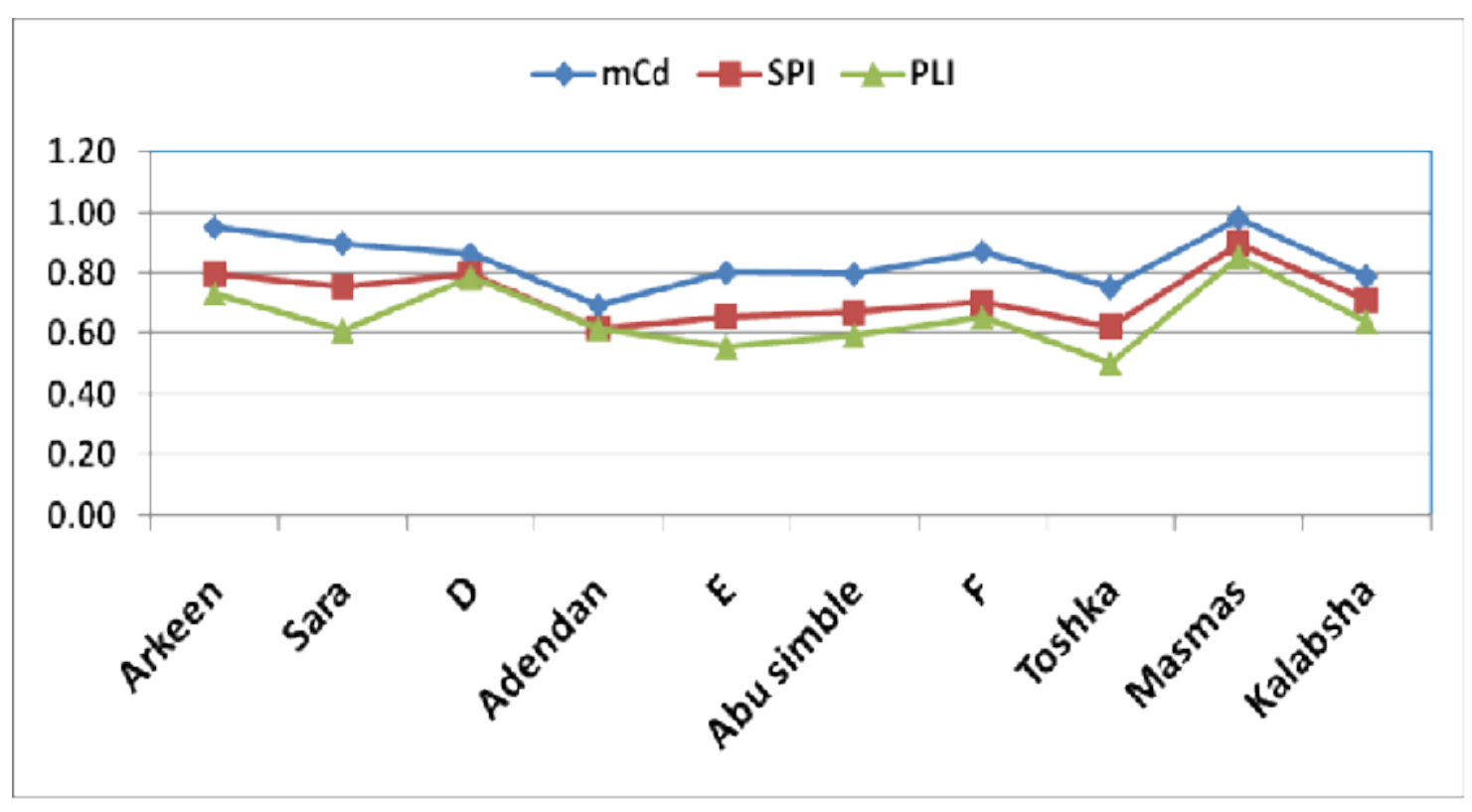

Fig. 7: $\mathrm{mC}_{\mathrm{d}}$, SPI and PLI in bed sediment along Lake Nasser

\section{Cluster of Variables}

The dendrogram displays the information printed in the form of a tree diagram. Dendrogram suggests indices which might be combined, perhaps by averaging or totaling.

The goal of cluster analysis of variables is to detect the hierarchy of interrelations among a set of indices of a data matrix. Figure 8 shows the dendrogram for the studied indices of all samples data set.

Along Lake Nasser different clusters were extracted as follows:

Cluster 1: Cd,mCd, PLI and SPI indices

Cluster 2: RI index

This data analysis gives an idea of how the single index should be compared and related to one another. For instance, within all the group of all samples, there was a stronger correlation between the groups of parameters.

It's worth to mention that, SPI was chosen as integrated indices compared with PLI, Cd and $\mathrm{mCd}$, taking into consideration the toxicity weight of metal. 


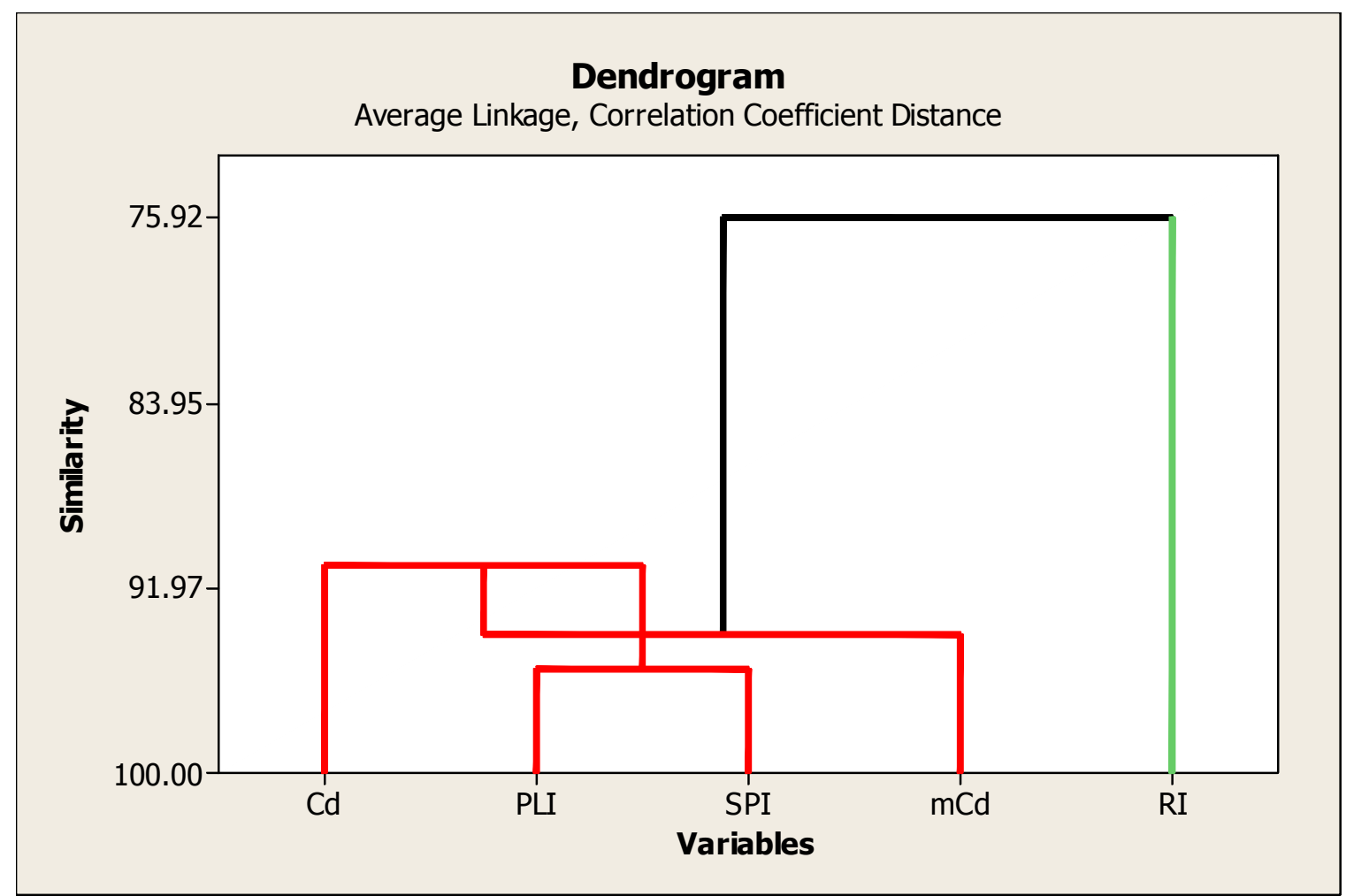

Fig. 8: Dendrogram of integrated indices

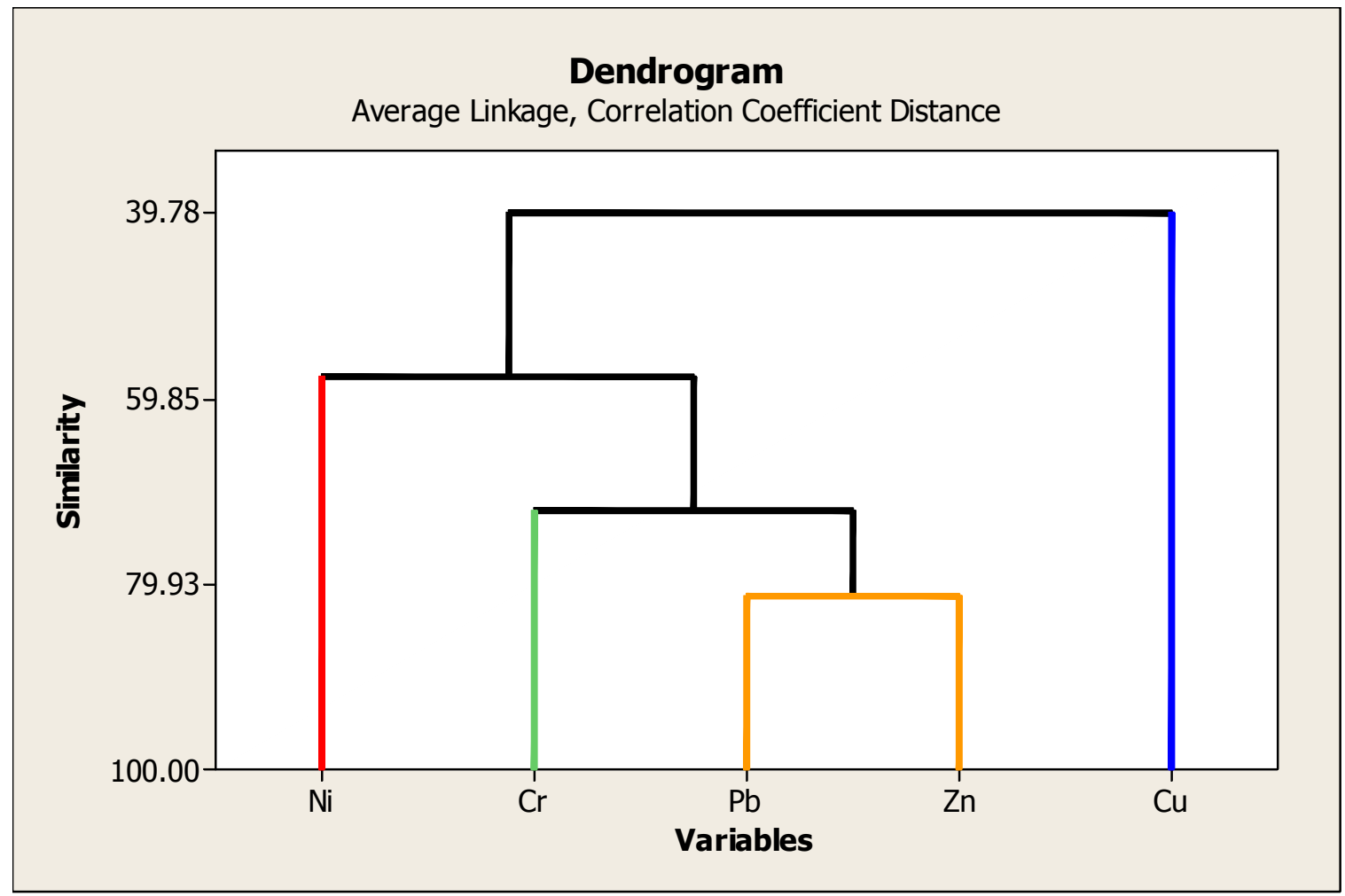

Fig. 9: Dendrogram of heavy metals based on SEF calculation 


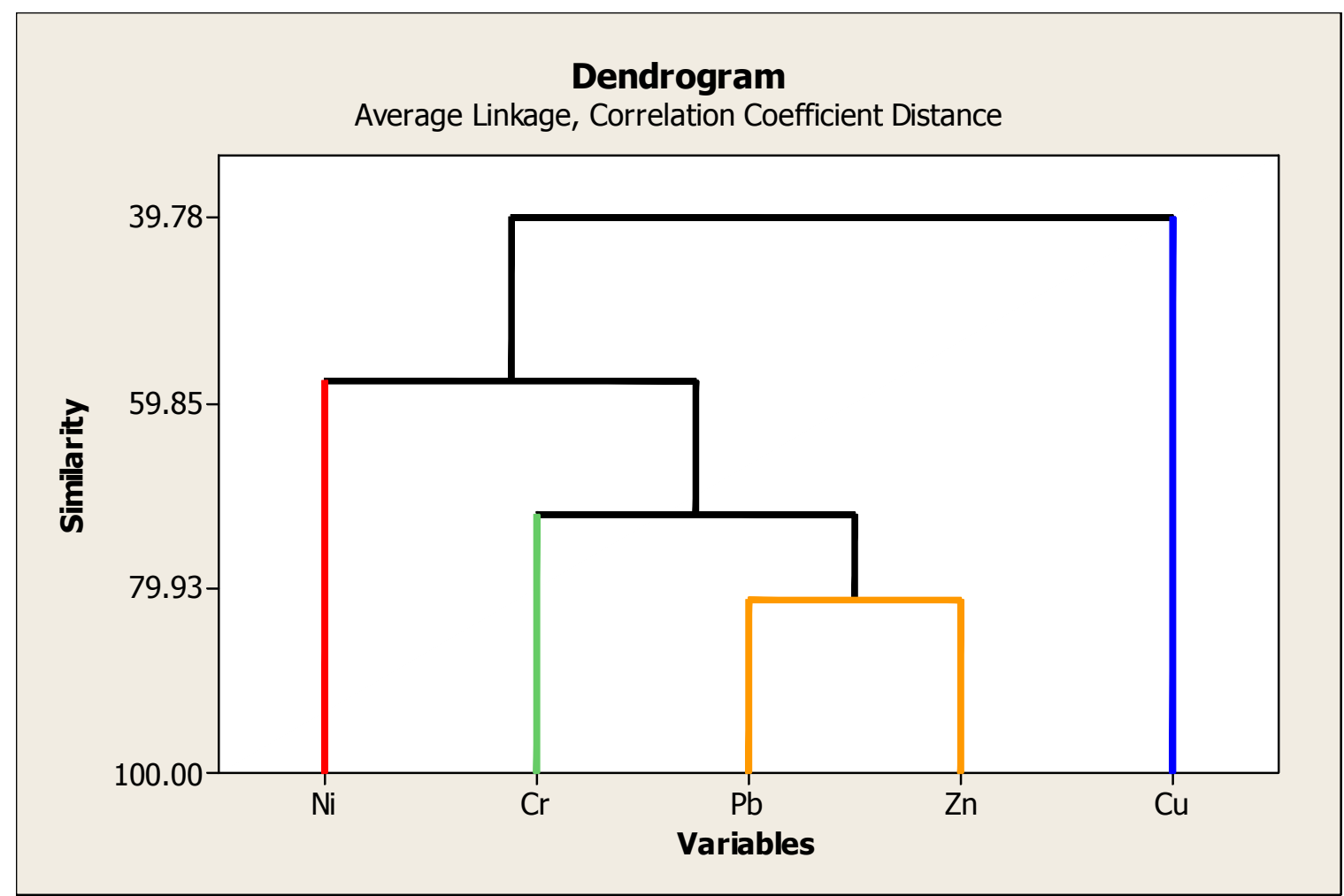

Fig. 10: Dendrogram of heavy metals based on Cf calculation

Figures 9 and 10 show the dendrogramof the studied heavy metals with respect to SEF and Cfcalculations of all samples data set. Along LakeNasser different clusters were extracted asfollows:

Cluster 1: Ni

Cluster 2: $\mathrm{Cr}, \mathrm{Pb}$ and $\mathrm{Zn}$

Cluster 3: $\mathrm{Cu}$

In general, the SEF and $\mathrm{Cf}$ have the same classification, but SEF is preferred than $\mathrm{Cf}$, where it gives the source of heavy metals.

\section{CONCLUSION}

In this work, seven heavy metals in surface sediments of Lake Nasser were investigated. Mean concentrations of heavy metals were found within the permissible limits of agricultural land use (Canadian Guidelines, 2007), except that of Copper which exceeds the value recommended by the standard. Cadmium and Arsenicwere not detected in all sites. The commonly used pollution indices by heavy metals in sediments were classified into two types of single and integrated indices. Four single indices of contamination factor and five integrated indices were also calculated. The results of metal assessment by indices indicating that, the studied area in Lake Nasser were unpolluted by total of studied heavy metals. Based on these indices for identifying the level of heavy metals of Lake Nasser sediments and applying cluster variables; the sediment enrichment factor, sediment pollution index and potential ecological risk index were chosen as the best over the other indices. The results also indicate that $\mathrm{Cu}, \mathrm{Zn}, \mathrm{Cr}, \mathrm{Ni}$ and $\mathrm{Pb}$ in the surface sediment were primarily derived from crustal origin and the natural processes such as weathering and erosion of bedrock are considered the main supply sources of heavy metals in sediments along Lake Nasser. 


\section{RECOMMENDATION}

It is recommended to applysediment enrichment factor, sediment pollution index and potential ecological risk indexas the best indices for heavy metals assessment. It is also recommended to establish Egyptian sediment quality Guideline.

\section{REFERENCES}

Binning, K. and Baird, D. (2001). Survey of heavy metals in the sediments of the Swartkops River estuary, Port Elizabeth South Africa. Water SA, 27(4): 461466.

Campbell, P.G.C. and Tessier, A. (1996). Ecotoxicology of metals in aquatic environments: Geochemical aspects. In: Ecotoxicology: A hierarchical treatment, M.C. Newman and C.H. Jagoe, eds. Lewis Publishers, Boca Raton. FL.

Canadian Environmental Quality Guidelines (2007). Canadian Council of Ministers of the Environment.

Caeiro, S; Costa, M. H. and Ramos, T. B., (2005). Assessing heavy metal contamination in Sado estuary sediment: An index analysis approach. Ecological indicators, 5: 151-1698.

Hakanson, L. (1980). An ecological risk index for aquatic pollution control: a sedimentology approach. Water Research, 14: 975.

Riba, I.; Del Valls, T. A.; Forja, J. M. and Gomez-Parra, A. (2002). Evaluating the heavy metal contamination in sediments from the Guadalquivir estuary after the Aznalcollar mining spill: a multivariate analysis approach, Environ. Monit. Assess., 77: 191-207.

Ruiz, F. (2001). Trace metals in estuarine sediments from the South-western Spanish Coast, Mar. Pollut. Bull., 42: 482-490.

Tomlinson, D. L.; Wilson, J. G.; Harris, C. R. and Jeffrey, D. W. (1980). Problems in the assessment of heavy metal levels in estuaries and the formation of a pollution index. Helgolaender Meeresunter, 33: 566-575.

Mackay. D. (2001). Multimedia environmental models: the fugacity approach, $2^{\text {nd }}$ ed. CRC press, USA PP., 39-44.

Bai, J. H.; Cui, B. S.; Chen, B.; Zhang, K. J.; Deng, W.; Gao, H. F. and Xiao, R. (2011). Spatial distribution and ecological risk assessment of heavy metals in surface sediments from a typical plateaulake wetland, China. Ecological Modelling 222: 301-306.

Jian, X.; Wang, W. W.; Wang, S. H.; Zhang, B. and Hu, J. C. (2012). Initial identification of heavy metals contamination in Taihu Lake, a eutrophic Lake in China. Journal of Environmental Sciences, 24: 1539-1548.

Varol, M. (2011). Assessment of heavy metal contamination in sediments of the Tigris River (Turkey) using pollution indices and multivariate statistical techniques. Journal of Hazardous Materials, 195: 355-364.

Sheikh, M. A.; Noah, N. M.; Tsuha, K. and Omoti, T. (2007). Occurrence of tributyltin compounds and characteristics of heavy metals, Int. J. Environ, Sci Tech., 4(1): 49-60.

Spencer, K. L. and Macleod, C. L. (2002). Distribution and portioning of heavy metals in Estuarine sediment quality standard, Hydrology and earth system science, 6: 989-998. 


\title{
ARABIC SUMMARY
}

\section{نهج حاسم لتقييم رسوبيات قاع بحيرة ناصر باستخذام المعاملات المختلفة}

\author{
محسن محمود يسري \\ معهد بحوث النيل - المركز القومي لبحوث المياه - القناطر الخيرية، مصر
}

تركز هذه الدراسة على توزيع المعادن في رسوبيات بحيرة ناصر كما أن الأهداف الرئيسية لهذه الدراسة

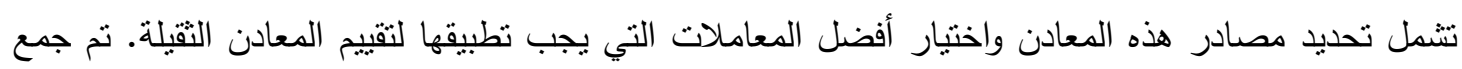

عينات الرسوبيات السطحية لعدد · ( مواقع على طول بحيرة ناصر (من قطاع كلابشة وحتي قطاع أرقين). تم تقدير نركيزات المعادن عن طريق Inductively Coupled Plasma وهي تتشمل الكادميوم، الزرنيخ، الكروم، الرصاص، النحاس، النيكل والزنك. وأظهرت النتائج أن الكادميوم والزرنيخ سجلت قيماً تحت مستوي القياس بجميع المواقع ونم ترتيب المعادن تبعا لمتوسط التركيز كالتالي النحاس> الزناسك>الكروم>النيكل>

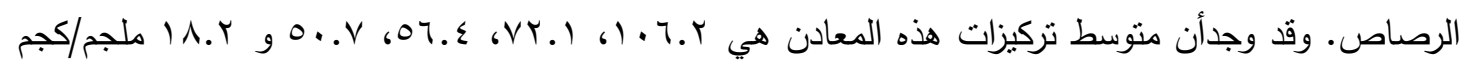
على الترتيب.

الثقييم البيئي لتلوث الرسوبيات بالمعادن الثقيلة نم باستخدام المعاملات المختلفة. معاملات التلوثهي أداة

قوية للتقييم البيئي الجيوكيمياء.

تم تصنيف معاملات تلوث الرسوبيات بالمعادن الثقيلة إلي نوعين من المعاملات الفردية والمعاملات

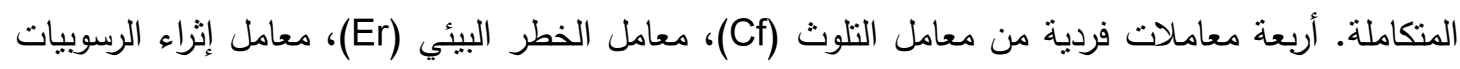
(SEF)

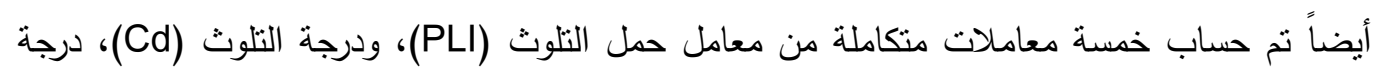

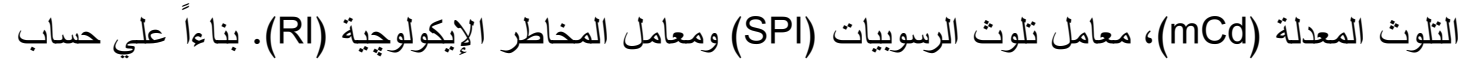
هذه المعاملات لتحديد مسنوى المعادن التقيلة برسوبيات بحيرة ناصر بجانب تطبيق التحليل الإحصائي (التحليل العنقودي للمتغيرات)، نم اختيار معامل إثراء الرسوبيات (SEF)، معامل نلوث الرسوبيات (SPI) ومعامل بلدئل

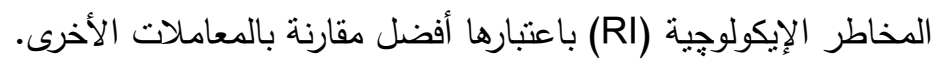

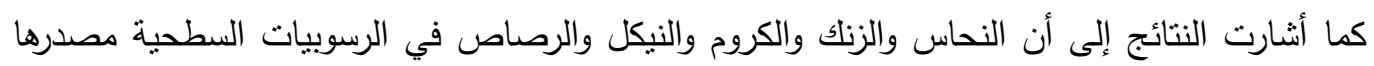

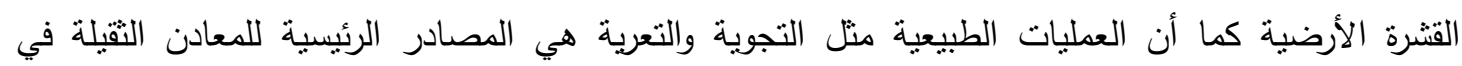
الرسوبيات على طول بحيرة ناصر . 